\title{
Phase II: The U.S. Experiment with an Incomes Policy
}

THE TERM "INCOMES POLICY" refers to a wide range of government measures for coping with what has been a major dilemma of western market economies in the post-World War II period-the need to reconcile a politically acceptable minimal rate of unemployment with a politically acceptable minimal rate of inflation. These policies have developed out of growing disillusionment with the ability of aggregate demand management, through traditional fiscal-monetary policy, to provide acceptable performance in both areas simultaneously. The incomes policies used have ranged from limited attempts to improve the functioning of individual markets through relatively mild voluntary programs (such as the wage and price guidelines that were introduced in the early 1960s in the United States) to complete government control of all wages and prices, such as has been applied during wartime.

European governments have generally been far more willing than has the United States to experiment with various kinds of incomes policies. But these experiments have had, at best, ambiguous results. Any general conclusion about their effectiveness is difficult because their objectives, the environment in which they were tried, and the formal arrangements have all varied widely. ${ }^{1}$

1. A general discussion of the experience of major European countries is presented in Lloyd Ulman and Robert J. Flanagan, Wage Restraint: A Study of Incomes Policies in Western Europe (Berkeley: University of California Press, 1971). A detailed examination of recent British experience is given in Allan Fels, The British Prices and Incomes 
With the introduction of its new economic policy in August 1971, the United States embarked on its own adventure with a major program for wage and price controls. Following the freeze that was in effect for three months, the new economic policy moved into its second phase of controlled increases in wages and prices. This paper focuses on the "Phase II" period - particularly on the form of the price and wage regulations, their effectiveness in slowing the overall rate of inflation, and their impact on other economic goals.

The wage and price controls were adopted after a series of earlier measures, undertaken in an effort to restrain inflation in the years 1969-71, had swollen the ranks of the unemployed by over two million persons, had reinforced inequities in the distribution of income, and had cost the nation over $\$ 150$ billion in lost output. In evaluating this or any other incomes program, problems, inefficiencies, and inequities certainly will be found; but they must be contrasted with those that would have existed without the program or with an alternative. The state of the economy over the last few years clearly shows that Phase II of the new economic policy did not replace an economic utopia.

The first part of this paper summarizes briefly the behavior of wages and prices up to the beginning of Phase II. The second outlines the structure of the control program and its major regulations. The third focuses on its impact as measured by the major price and wage indexes. The paper concludes with a more subjective discussion of some of the problems and issues that have developed during the time the program has been in operation.

\section{Prelude to Controls}

The years prior to the freeze and Phase II bear ample witness that price and wage controls were not viewed as a first line of defense against inflationary pressures. In fact, the government showed remarkable forbearance in exhausting most of the traditional alternatives.

Board (London: Cambridge University Press, 1972). See also Organisation for Economic Co-operation and Development, Inftation: The Present Problem, Report by the Secretary General (Paris: OECD, 1970), for review of some countries that are not covered in the Ulman and Flanagan book. 


\section{THE 1960-65 PERIOD OF PRICE STABILITY}

The early 1960s still stand out as a time of remarkable price stability. The consumer price index (CPI) advanced at the rate of 1.3 percent a year from 1960 to 1965, with most of the increase occurring in the service sector - an area of particularly low productivity growth. (See Table 1.) ${ }^{2}$ Nonfood commodity prices rose at an average rate of 0.5 percent, and prices of durable goods actually declined. Wholesale prices rose by only 0.3 percent a year, with the industrial component remaining nearly constant from 1959 to the end of 1964. Food and consumer goods prices increased more rapidly in the CPI than in the wholesale price index (WPI), reflecting the low rate of productivity growth in trade and transportation. ${ }^{3}$

Wage increases were also quite moderate during the early 1960s, as is shown in Table 2. Two major measures of wage costs are available at the level of the aggregate private nonfarm economy - total compensation per manhour and a fixed-weight earnings index. While the series on total compensation per manhour is an adequate long-term measure of wage costs, it is quite erratic in the short run, perhaps because it draws on two different sources for data on compensation and on manhours. ${ }^{4}$ Differences in computation procedures, the inclusion of overtime pay, and cyclical changes in the distribution of employment between high- and low-wage industries are major contributors to the observed short-run variability. The earnings series differs in that it excludes fringe benefits and the income of nonpro-

2. The nonfood components of the consumer price index have been adjusted to eliminate the influence of mortgage interest rates, used car prices, and the auto excise tax reduction, and all the indexes are seasonally adjusted except services and rent, which have no significant seasonal variation. Interest rates and used car prices have substantial short-run fluctuations that at times distort the underlying inflation trends. The methodology used for these adjustments was not as detailed as that used by the Bureau of Labor Statistics. The two components were treated as part of a fixed-weight index, with relative importance for December 1971 as weights. However, any biases should be of minor importance for the period studied. This adjustment is not of significance in the 1960-65 period but does affect the interpretation of later price movements. The aggregate CPI index shown in Table 1 is the same as that published by the Bureau of Labor Statistics.

3. A study of productivity trends in the trade and service sectors can be found in Victor R. Fuchs and Jean A. Wilburn, Productivity Differences Within the Service Sector, Occasional Paper 102 (Columbia University Press for the National Bureau of Economic Research, 1967).

4. The compensation data are from the U.S. Department of Commerce, Bureau of Economic Analysis, and the manhours data are from the Bureau of Labor Statistics. 


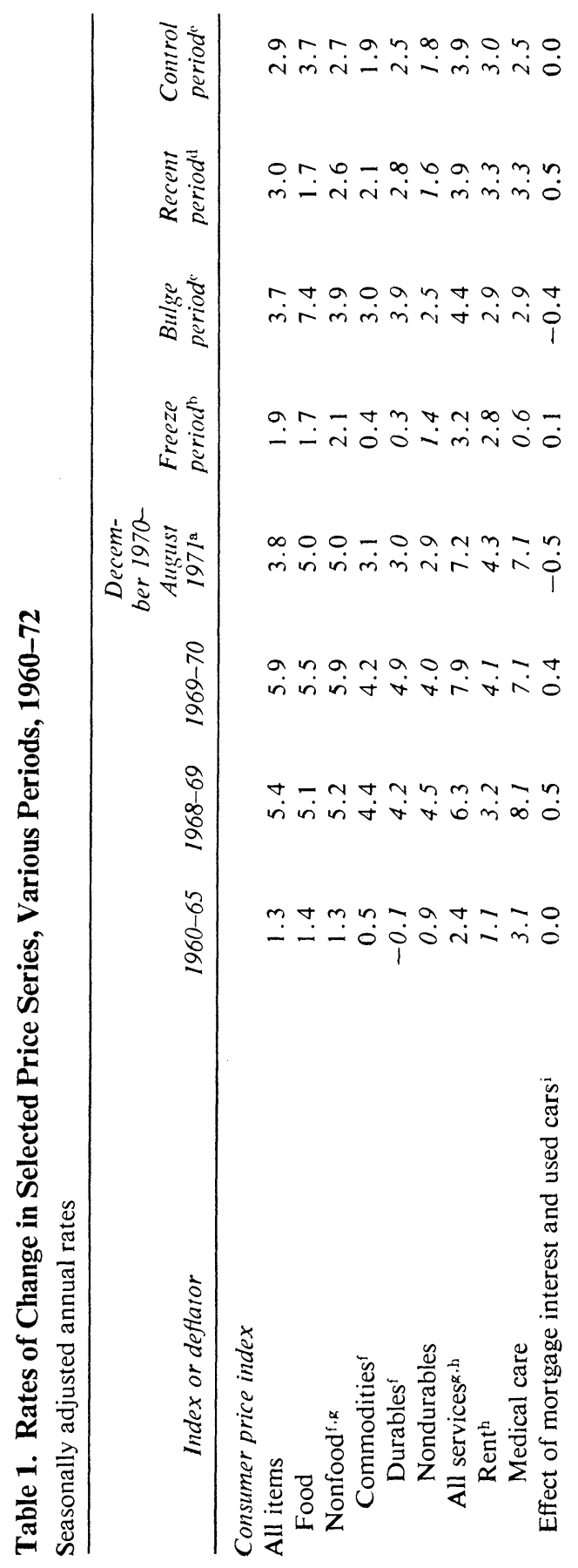




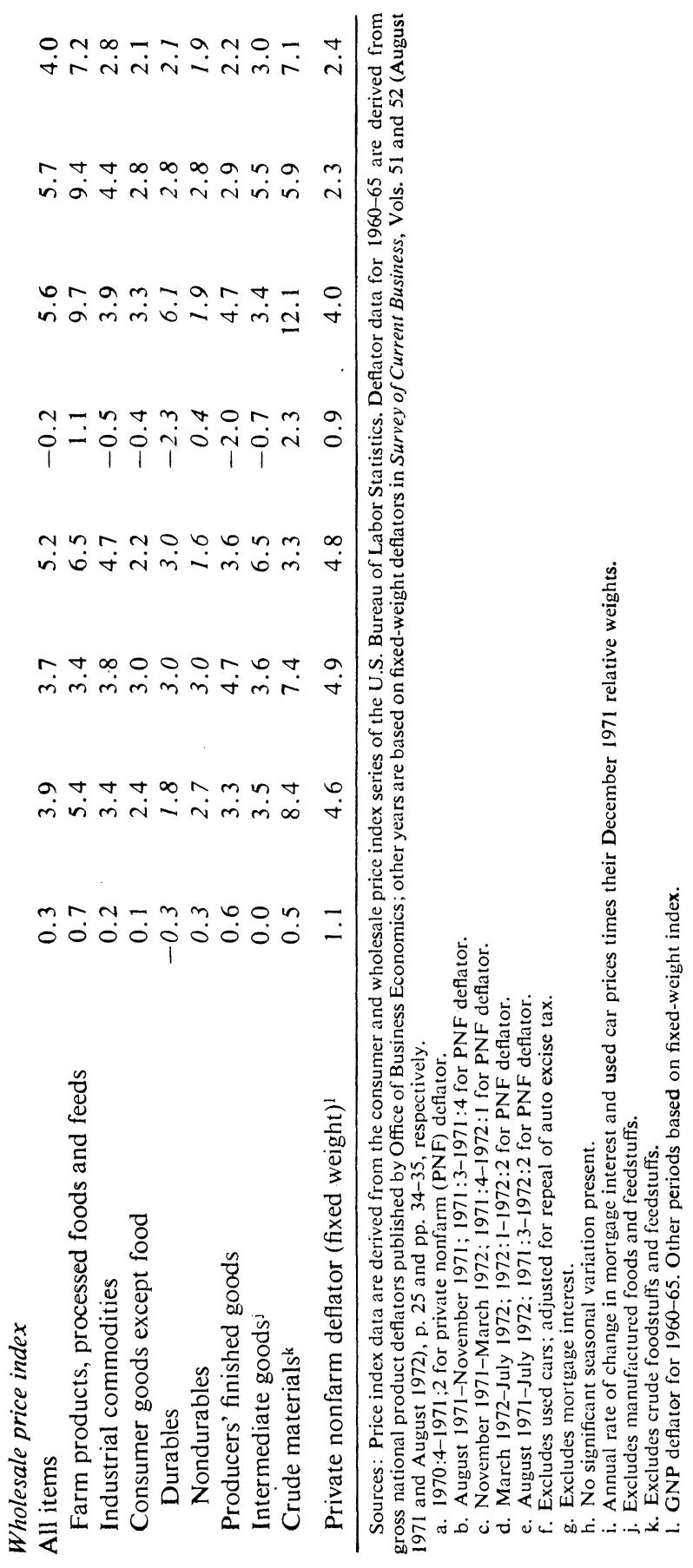




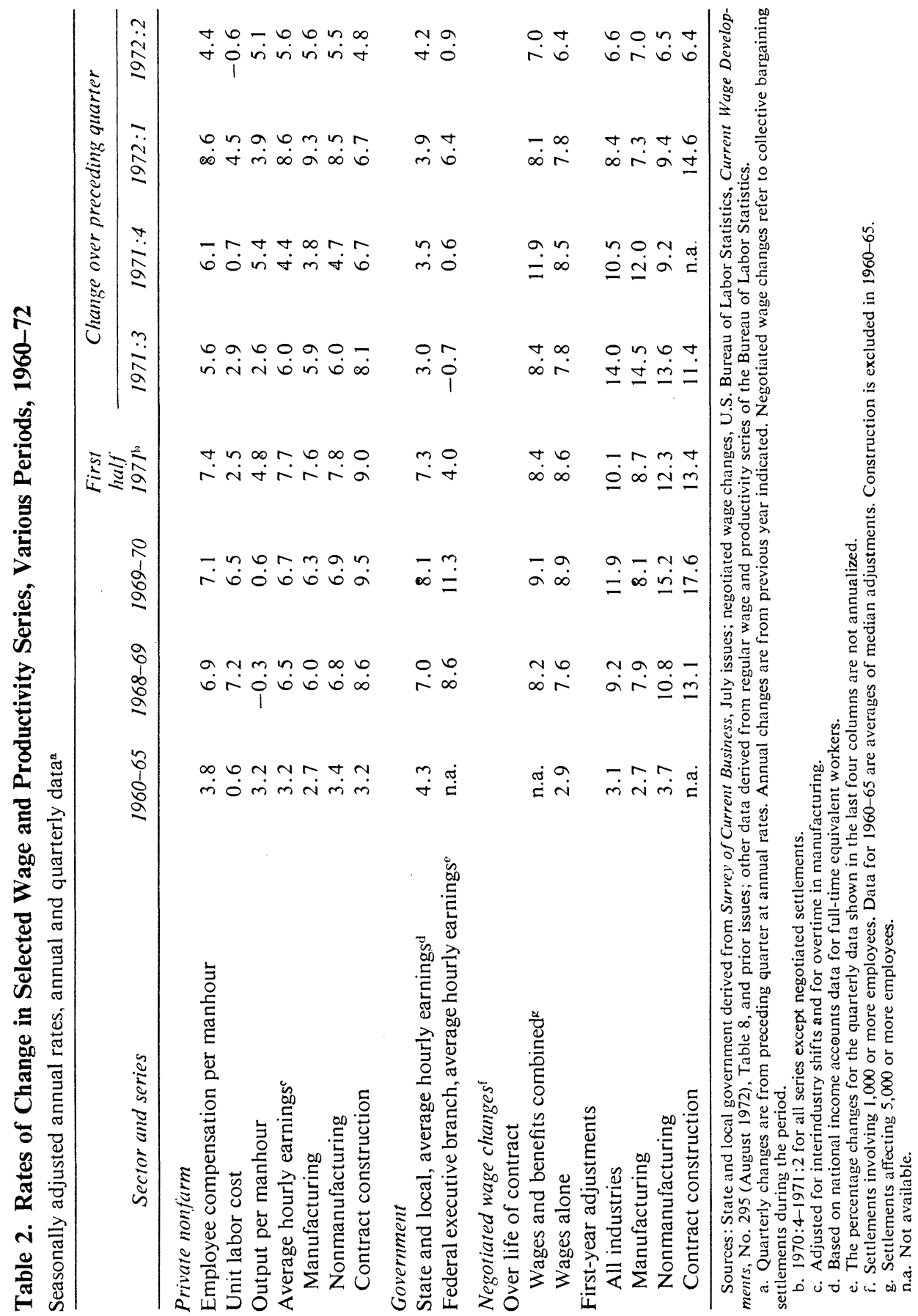


duction workers and is a fixed-weight index, which reduces the importance of interindustry employment shifts and variations in overtime within manufacturing.

Employee compensation per manhour in the private nonfarm sector grew at an average annual rate of 3.8 percent from 1960 to 1965 . Since this exceeded only slightly the rate of increase in output per manhour, unit labor costs were relatively stable. Average hourly earnings of production workers grew less rapidly than the total hourly compensation of all employees, reflecting partly a rapid rise in fringe benefits, as well as an apparently higher rate of wage or salary increase for nonproduction workers. Wages of government employees rose somewhat faster than those in the private sector.

Various hypotheses have been put forth to explain the favorable performance of prices and wages during this period, in which the unemployment rate declined steadily from a high of 7 percent in May 1961 to 4 percent by the end of 1965. ${ }^{5}$ Several studies have found that the wage and price guideposts played a significant role. Others have emphasized the shifts in the composition of the labor force, especially the high level of "disguised unemployment" of women and teenagers. Still other studies infer that the tradeoff between inflation and unemployment becomes steep only when the unemployment rate is in the 4 to 4.5 percent range and is subject to substantial time lags. On this view, the initial stability of prices and high level of unemployment produced a noninflationary period that could not last at a maintained low rate of unemployment. In any case a single experience cannot provide a basis for choosing among all of these hypotheses, and a full explanation is complicated by the fact that there is probably some truth in all of them.

\section{OUTBREAK OF INFLATION}

More rapid price increases became evident in late 1965 and in 1966 . The sharp increase in defense spending for the Vietnam war in 1965 strengthened

5. For an introduction to this literature and a bibliography see Robert J. Gordon, "Inflation in Recession and Recovery," Brookings Papers on Economic Activity (1:1971), pp. 105-58; George L. Perry, "Changing Labor Markets and Inflation," Brookings Papers on Economic Activity (3:1970), pp. 411-41; and George L. Perry, "Wages and the Guideposts," American Economic Review, Vol. 57 (September 1967), pp. 897-904. A detailed discussion of the guidepost experience is given in John Sheahan, The WagePrice Guideposts (Brookings Institution, 1967). See also George P. Shultz and Robert Z. Aliber (eds.), Guidelines, Informal Controls, and the Market Place: Policy Choices in a Full Employment Economy' (University of Chicago Press, 1966). 
demand pressures just as the rate of unemployment reached 4 percent. In addition, farm prices increased sharply, thus intensifying the concern of workers with their real incomes. War-related demands on individual sectors led to relatively large price increases for some commodities, such as raw materials and equipment. Medical care prices were a major source of acceleration in the services sector, perhaps as the result of a sharp spurt in demand for medical services following the introduction of medicare without the provision of adequate new resources to meet this demand.

By the middle of 1966, with the settlement of the airline machinists' contract, the guideposts had become largely ineffectual in restraining wage increases. Manufacturing wage adjustments, which had been particularly moderate in the earlier period, rose sharply during 1966, and most of the major wage indexes showed significant acceleration.

Wages and prices rose less rapidly during the mini-recession of 1967 but surged upward in all segments of the economy with the renewal of rapid demand growth in late 1967 and 1968.

A combination of monetary and fiscal restraint sharply reduced the rate of expansion and pushed the economy into recession by the end of 1969 . The growth rate of real gross national product (GNP) slowed from 5.8 percent between the first and third quarters of 1968 to 3.8 percent in the next two quarters and actually became negative over the following four quarters. The unemployment rate rose from 3.3 percent in late 1968 to over 4 percent in early 1970 and soared to 6 percent by the end of the year.

Stabilization policies clearly did influence economic activity, but wages and prices failed to respond to the deceleration of aggregate demand growth. As is reflected in all of the major components of the CPI and WPI, the rate of inflation in prices continued to rise across the board in 1969 and 1970. The major wage indexes given in Table 2 also show acceleration, especially in the collective bargaining area, in the face of a very substantial increase in unemployment. The pressure of large wage increases on prices was intensified by the very weak performance of labor productivity in both 1969 and 1970. Output per manhour in the private nonfarm sector actually declined in 1969 and increased by only 0.6 percent in 1970, in contrast with the postwar average annual growth rate of nearly 3 percent.

The behavior of the CPI in early 1971 provided some grounds for optimism. It rose at an annual rate of 3.8 percent in the eight months prior to the August 1971 freeze, down from 5.9 percent in 1970. However, a closer examination of the data reveals some of the reasons why this performance 
did not satisfy the administration in August. A large decline in mortgage interest rates, in response to an easier monetary policy, accounted for a significant portion of the supposed improvement. In addition, the August index was lowered by the removal of the automobile excise tax. Thus the adjusted index of nonfood items (excluding the effects of mortgage interest rates, used car prices, and the removal of the automobile excise tax) continued to rise at a 5 percent rate, although it slowed down somewhat from its 1970 pace in both the commodity and service components. Because of a substantial rise in the price of intermediate goods, the outlook for wholesale prices also was clouded.

The behavior of wage rates raised even more doubt that an end to inflation was in sight. A sharp cyclical upturn in productivity did produce a marked slowdown in the rise of unit labor costs, but hourly compensation and earnings accelerated in most major categories. The negotiated wage increases abated slightly, almost entirely as a result of the reduction of construction settlements after their extraordinary 17.6 percent advance in 1970.

It is hard to explain the persistence of inflation in the 1969-71 period in the face of a major decline in the rate of overall resource utilization. Partial explanations have been proposed by others. Statistical equations, such as those of George L. Perry and Robert J. Gordon, ${ }^{6}$ may improve our understanding of the change in wage behavior between the first half and the last half of the 1960s, but they do little to explain the persistence of large wage increases in 1970 and 1971. Despite the secular changes in the age and sex composition of the labor force, labor markets became much easier in 1970 by whatever measure is used.

Inflationary expectations may have played a part, but to have offset the large change in unemployment they would have had to become effective coincidentally with the 1970 recession. The statistical work in this area is marred by the strong two-way causation between prices and wages. If wages increase abnormally for any reason, they soon boost prices, and the direction of causality can easily become obscured. Inflationary expectations are sometimes invoked as an explanation in a residual category of hypotheses sweepingly applied to those episodes that are not fully understood.

The basic difficulty in choosing among possible explanations of observed

6. See Robert J. Gordon, "Wage-Price Controls and the Shifting Phillips Curve," in this volume. 
wage and price behavior is the unique nature of each of the inflationary episodes. The postwar data for the United States do not offer much repetition of market conditions, particularly in the labor market. Despite the use of quarterly data the degrees of freedom for meaningful statistical analysis are limited to at most five or six relatively independent episodes.

A concern with relative wages rather than real wages may have been a major element in the stubbornness of inflation from 1969 through 1971. Individuals may not be acutely aware of the magnitude of increases in the average price of the goods they buy, but they are well informed about the wages of other groups with whom they feel competitive. Recent wage settlements in related industries serve as basic starting points for current negotiations. When wages accelerate in response to demand pressures or other factors in one industry, a general round of wage increases may be triggered off as other industries seek to restore what they regard as the correct relative wage structure. Union members in particular may use such settlements as criteria for judging the performance of their leaders at the bargaining table.

Management's standard for an acceptable settlement is also likely to be strongly conditioned by earlier settlements in other industries. The goal is not to defeat the union or break a strike, but rather to achieve a wage settlement that is not out of line with what competitors are likely to grant and that does not result in extreme worker dissatisfaction.

This kind of informal tandem bargaining is quite evident in several of the major union contracts. Settlement terms in aluminum, cans, and steel were notably similar, as were those in automobiles, farm implements, and the aerospace industry. This concern with relative wage positions, together with increased use of multiyear contracts, extends the rounds of wage increases far beyond the period of original stimulus; for example, wage rate increases for the major unions fell behind in the 1965-68 period, thus creating pressures for larger subsequent increases.

The emphasis on wage rounds and relative wage positions in empirical work has not advanced far beyond the study published by Eckstein and Wilson in $1962,{ }^{7}$ partly because such hypotheses are not readily amenable to popular statistical techniques, such as regression analysis. But the Phillips curve approach, which relates inflation to resource utilization, also did not serve policy makers or forecasters well.

7. Otto Eckstein and Thomas A. Wilson, "The Determination of Money Wages in American Industry," Quarterly Journal of Economics, Vol. 76 (August 1962), pp. 379414. 
Most economic forecasts consistently underpredicted the magnitude of price and wage increases that occurred during the years 1969-71. Reflecting the same convictions, administration economists stuck with their "game plan" of applying restrictive stabilization policies as a cure for the inflation, giving these policies two and a half years to produce some evidence of success. U.S. economists appear to have placed too much faith in depressing resource utilization as a means of curbing inflation in highly institutionalized market economies, such as are found in the developed western countries. If that lesson is properly read, the experience in the years 1969-71 should show that there are no simple explanations for complex economic behavior and no easy solutions to the problems.

\section{FREEZE PERIOD}

The administration finally abandoned the game plan in August 1971 and imposed a broad ninety-day freeze on wages and prices. This provided time for developing a control program, without the risk of price and wage rises under the pressure of rumors and inside information. It also prevented the kind of inequities that developed in late 1950 as a prelude to the Korean war controls, when sharp increases in prices occurred in anticipation of controls and particularly harmed union workers and businessmen who were locked into long-term contracts. Some contracts were reopened during the Korean war but this was not done on a consistent basis.

A freeze that continues for any significant time does place a burden on labor since the increased productivity of labor leads to higher profits rather than higher wages. Moreover, a freeze hurts those who had earlier contracted for price and wage increases. If these were allowed, however, it would complicate the freeze program since price relief would have to be granted to firms that experienced major contractual increases in their costs and wage relief to nonunion workers who would have received wage increases during the period on the basis of traditional practice. The administrators were already strained to develop machinery to administer the recent freeze and probably could not have handled any more complex problems.

In stopping the rise in wages and prices, the freeze was quite successful. Most of the observed rise in the CPI was brought about by rises in exempt areas, such as food and taxes. An examination of the available monthly data on wages strongly supports the impression that the freeze was also 
almost fully effective on the wage side, even though that is not clear from the quarterly data in Table 2, which do not strictly isolate the freeze period. Furthermore, the compensation data in the table include subsequent retroactive payments of wage increases already scheduled to become effective during the time of the freeze, and earnings data reflect fluctuations in overtime.

\section{Organizational Structure and Regulations}

Phase II followed the freeze, beginning in mid-November 1971. General administrative control of the Phase II program lies with the Cost of Living Council. The council has the responsibility of specifying which economic units are to be subject to the controls, classifying these units with respect to prenotification and reporting, and supervising the Treasury Department's Internal Revenue Service in its operation of the local service and compliance centers.

A three-tier system of controls has been set up by the council. All tiers are subject to the same standards but differ in the degree of reporting required. The first, which includes the largest firms and employee bargaining units (employee units with 5,000 or more workers, and companies with sales of $\$ 100$ million and over), is required to obtain prior approval for wage and price adjustments. A second group, of smaller economic units (units with 1,000 to 5,000 workers, and companies with sales between $\$ 50$ million and $\$ 100$ million), is required to submit regular ex post reports of any adjustments. A third group, of still smaller units, is not required to submit reports but is subject to the standards for category I and II units and may be audited. In addition, substantial elements of the economy have been exempted from the controls, among them, raw food products, small firms and employee units, low-wage employees, home purchases, used products, and small rental units.

The significant price and wage decisions are made by the Pay Board and the Price Commission. In addition, there are several ancillary committees, including a Committee on Interest and Dividends, and two special advisory committees-the Health Service Industry Committee and the Committee on State and Local Government Cooperation. 


\section{THE PAY BOARD}

The Pay Board was originally composed of fifteen members, with equal representation of labor, business, and the public. As might have been expected, the initial meetings of such a diverse group were not conducted in an atmosphere of great amiability; nonetheless the board emerged with a workable program and the cooperation, if not the enthusiastic support, of the labor faction. The dominant issues at these earlier meetings concerned a general standard for new contracts, the treatment of deferred increases under agreements signed prior to the controls, and the disposition of retroactive payments of wage increases held up by the freeze.

General standard. The standard for new contracts was particularly significant in that all three parties were in agreement that overall wage increases should be based on the trend in productivity of the overall economy and on prospective increases in the cost of living. Except for the inclusion of cost-of-living increases, this was the basic concept underlying the guidelines of the early 1960s. The standard reflected the trend rather than cyclical productivity and, most important, it was based on an economy-wide rather than an industry-specific productivity figure. ${ }^{8}$

The 5.5 percent limit on new wage contracts set by the Pay Board reflected a target rate of inflation of 2.5 percent and an estimated 3 percent for the long-run rate of increase in productivity. This general standard was qualified for two major reasons: to reflect historical tandem wage relationships and to allow a catchup for multiyear contracts that were signed prior to 1969 . The intent of the tandem exception was to provide a link with precontrol wage increments where the introduction of the wage freeze caught some industries (such as steel) halfway through the negotiating process, despite the fact that the basic key agreement had already been signed.

Catchup. The catchup provision (now scheduled to expire in November 1972) was intended to allow an additional increase of up to 1.5 percent for employee units that had signed agreements in 1968 and earlier years in anticipation of moderate future wage and price increases. Since these groups had not benefited from the subsequent explosive wage increases, the deterioration of their relative wage position tended to distort relative

8. The use of industry-specific productivity would result in a substantial widening of wage differentials between low-productivity and high-productivity industries without reference to the relative supplies of labor. 
labor market conditions. The catchup was computed as the difference between 7 percent, the economy-wide average wage increase in the previous three years, and the annual average wage increase received under the old contract. Further, the catchup was limited to no more than 1.5 percent, thus making the maximum possible wage increase 7 percent (the sum of the 5.5 percent basic standard and the maximum 1.5 percent catchup).

The catchup provision was substantially broadened later when it was made applicable to wage agreements other than multiyear contracts. These included previous one-year union settlements and the wages of nonunion workers, even though the pay of these workers had not been restrained by a prior contract during the earlier inflation. With this new interpretation, eligibility for a 7 percent increase was extended to nearly one-half of all wage earners instead of the relatively small number covered by multiyear contracts that expired in 1972. In June 1972 the board acted to restrict the catchup provision to employee units with an average straight-time wage rate of less than $\$ 3.00$ an hour and thus reduced the number of workers eligible for the catchup provision to 20 to 25 percent of the work force. However, since the board reviews contracts only after negotiations between the employees and employers are completed, this is not an estimate of the number of workers who will receive a wage increase above the basic standard: They must first obtain one from their employers.

Deferred increases. Deferring increases under existing contracts raised a significant issue in that it meant invalidating legal contracts that were signed before the controls were instituted. Unions have fought long and bitter battles in the not so distant past to establish their right to negotiate collective agreements and to represent and protect the interests of employees. Because unions have respected the binding nature of these contracts, the United States has been largely free of the wildcat strikes and failure to comply with the terms of agreements that have plagued other countries - the United Kingdom, for example. The unions stressed the view that, since multiyear contracts may involve the surrender of some interests by the union early in the contract period in exchange for later wage increases, to reduce or eliminate these increases without considering the rest of the contract would be inequitable.

The sanctity of existing contracts was preserved by a change in emphasis that was principally semantic. Existing contracts were viewed as valid and allowed to take effect subject to a specific challenge by a subgroup of the Pay Board or by one of the parties at interest. This contrasted with the re- 
quirement of prior notification and approval for new contracts. There appears to have been an implicit understanding that the standard for these challenges would not be lower than that for new contracts and rarely would affect contracts providing less than a 7 percent increase. In recent months the board's treatment of deferred increases has moved closer to that for new contracts, with a requirement for prenotification in categories I (firms with 5,000 or more employees) and II (1,000 to 5,000 employees), and an automatic challenge and review of increases of more than 7 percent.

The issue of the retroactive payment of wage increases held up by the freeze was regarded by all parties as a matter of principle, on which there could be no compromise. Labor insisted that it must be paid, while the public and business members strongly opposed this view. The question of the retroactive payments, despite their minor economic significance (about $\$ 1$ billion), remained a major source of friction within the board until Congress ordered their payment.

The stabilization act that was finally approved by Congress required several significant modifications in the Pay Board rules. First, the act exempted from the controls several major fringe programs, such as private pension plans, profit sharing, and group insurance programs. While the rationale for this is difficult to interpret, it may reflect the legislative influence of certain interest groups, such as insurance companies. The exemption was qualified by a limitation on increases that were "unreasonably inconsistent." When the Pay Board applied a numerical definition to this term, the exemption had the effect of raising the basic 5.5 percent standard to 6.2 percent.

Second, Congress exempted the "working poor" from wage controls, which raised a problem of definition. Are the working poor those with minimum adequate budgets or those at the poverty level? Furthermore, the need to translate a family's income into that of a single worker created difficulties. The Cost of Living Council saw the dividing line as $\$ 1.90$ an hour - the administration's proposed minimum wage. This position was later overturned by a court ruling that it did not reflect the intent of Congress. The current figure is $\$ 2.75$ an hour.

Finally the Economic Stabilization Act required the board to permit exceptions to the general standard in the case of agreements that reflected direct increases in employee productivity (such as incentive pay plans). The board has also made some exceptions to the general standard when the wage contract included a buying out of restrictive work rules. 


\section{THE CONSTRUCTION INDUSTRY STABILIZATION COMMITTEE}

The Construction Industry Stabilization Committee (CISC) was established before the Pay Board, but since the beginning of Phase II it has continued to operate under the delegated authority of the board. Unlike the Pay Board, the committee continues to be a tripartite organization. Its jurisdiction was limited initially to increases under new contracts, and it had no clear authority to hold up deferred wage increases. A general standard of 6 percent for new contracts was applied, but frequent use has been made of its exceptions provisions. ${ }^{9}$ These exceptions raised average settlements to 13.4 percent in early 1971 .

Since the beginning of Phase II, the committee has operated within the framework of the general pay standards, with power to limit new increases and to challenge all deferred increases. It also has considerable latitude in applying the regulations to individual cases, its basic commitment being to bring the average increase in construction wages back into line with that of the rest of the economy.

The explosion of construction wage rates in earlier years had seriously distorted relative wage structures, and rates for the same job varied widely among local areas. Pay in skilled jobs occasionally was less than that in unskilled ones if the former was limited by a long-term contract. Thus the catchup problem was greater in the construction industry than elsewhere. The committee has tried to restore historical wage differentials and to create a greater degree of homogeneity of wage rates for similar jobs, on both a regional and a national basis.

\section{THE PRICÉ COMMISSION}

The Price Commission has seven members. While no attempt was made to represent all areas of interest, several of the members have substantial prior business experience. The commission established a set of rules that differ for major sectors of the economy but that were designed to hold the rate of inflation to 2.5 percent or less by the end of 1972 . Specific regulations were adopted for trade, manufacturing and services, public utilities, rental units, and health services. The basic approach adopted by the commission was to control prices indirectly by controlling profit margins on an in-

9. The operation of the CISC has been discussed in greater detail in Albert Rees, "The Construction Industry Stabilization Committee: Implications for Phase II," Brookings Papers on Economic Activity $(3: 1971)$, pp. 760-65. 
dividual firm-by-firm basis. The primary regulation allowed for the passthrough of costs, but these costs were defined to include everything except profits.

The commission has also applied a general rule requiring firms that receive price increases to maintain a profit margin per dollar of sales that is below the average of the highest two out of three fiscal years prior to the control program. The base profit margin for most firms is that for 1968-69. This rule was intended initially as a second "line of defense" after the cost pass-through standard and other more specific regulations. However, these detailed regulations have been difficult to implement, and increasing stress has been placed on controlling the profit margin.

Wholesale and retail trade. Price control regulations for wholesale and retail trade require firms to maintain a percentage gross markup over invoice cost that is no higher than that of the freeze period. Thus only increases in the cost of goods to the firm can serve as a basis for an increase in the price at which it sells them. The regulation does not allow for any increase in gross margins to reflect higher operating costs in the trade sector. Since the growth in productivity of the trade sector is less than that of the rest of the economy, while its rate of wage increase approximately matches the economy-wide average, the gross markup would normally be expected to rise in the long run. Thus the present regulation does have an extra degree of restraint beyond a cost justification of price increases.

The regulation is clear, and it is easy for firms to comply with it since it follows the line of their normal pricing procedures. However, the loose definition of the "normal margin" and shifts in product mix complicate its enforcement. It is not clear that a controls program should concentrate on the trade sector, which is considered to be quite competitive. The commission does focus on the large retailers and exempts those with fewer than sixty employees. The posting of base period prices for major sale items caused some confusion initially since it had no relationship to the basic regulation, which refers to markups and not prices. But this requirement is of little current importance.

Manufacturing and service firms. The regulation for the industrial sector is far more detailed, with an allowance for a percentage pass-through of all cost increases-costs being revenue less operating profits, as narrowly defined. These allowable cost increases are divided into four categories: unit labor costs adjusted for prospective productivity increases, unit material costs, other unit operating costs, and unit overhead costs. 
Initially the commission allowed firms to use their own estimates of productivity improvement, but this penalized firms that had achieved large gains in productivity, either through efficient management or through labor-saving investment. Moreover, it resulted in abnormally low estimates of future increases in productivity by firms that were asking for price increases. The commission now applies industry-wide productivity estimates to individual firms, using trend estimates rather than the above-trend growth associated with the present cyclical upswing. In applying for a price adjustment, individual firms still may estimate their own anticipated sales growth, which is important in determining the change in unit overhead costs. A low projected sales growth tends to raise the estimated increase in unit fixed costs. The initial period for measuring allowable cost increases was also changed from the date of the previous price rise to no earlier than January 1, 1971, in order to curb price increases by firms that had not raised prices in several years.

In an attempt to reduce the administrative load on multiproduct firms and on its own staff, the commission also entered into term limit pricing agreements (TLPs) with individual firms. Under these arrangements the firms agreed to hold their average price increases to 2 percent, but they were free to raise prices of individual products by any amount. After some experience with the provision, the commission lowered the overall limit on TLPs to 1.8 percent and put a ceiling on any individual increase, first at 8 percent and later at 6 percent.

Regulated utilities. The commission essentially delegated authority in the utilities area to the existing regulatory agencies, but retained the power to review and modify their decisions. The regulatory agencies are expected to follow the general criteria that apply to other industries, but it seems probable that they will simply continue their past practices. The intent of this decision was to prevent dual controls and to free the commission to focus on other sectors.

Health services. The regulations adopted for health services are somewhat more stringent and direct than those in other areas. A 2.5 percent ceiling applies to all increases in doctors' and dentists' fees, and they must be justified by cost increases. Health institutions also must cost-justify their price increases, with increases in excess of 6 percent being allowed only if an exception is granted by the commission.

Rent. The control of rental units is one of the most controversial areas of the program. Many observers question the need for and advisability of 
controls in this area because of their complexity and inequities and because of the basically competitive structure of the industry. The regulations do exempt about one-half of this market; and, where applied, the basic controls allow for a 2.5 percent increase for general costs, the pass-through of increases in taxes and charges for municipal services, and a recovery of the cost of capital improvements.

\section{Impact of the Controls}

Because the Phase II program has been in force for only a short time, it is difficult to draw any firm conclusions about its effectiveness. However, some tentative impressions can be reported concerning the impact of the program on the aggregate wage and price indexes. Most of the relevant statistical data are shown in Tables 1 and 2.

\section{IMPACT ON WAGE RATES}

Very few major union agreements are subject to bargaining in 1972. Major contracts (those affecting 1,000 or more employees) for 2.8 million workers are coming up for renegotiation or reopening in 1972, compared with approximately 4.75 million in both 1970 and 1971 . However, the largest of these occurred relatively early in the program, before many of the regulations were formalized. These included union agreements in the coal (in late 1971), aerospace, railroad, and longshoring industries. The rest of the year has been dominated by negotiations of relatively small or regional unions, most notably in the construction, trade, and apparel industries.

Because so many multiyear contracts were signed in 1970 and 1971, deferred increases under those contracts are an important element in the wage record of 1972. According to Bureau of Labor Statistics records, these deferred increases average 6.1 percent for the year, excluding escalator clauses, and cover 6.7 million workers under major labor contracts (those affecting 1,000 or more workers). The largest are in construction (11.6 percent), transportation ( 9.5 percent), and trade ( 7.7 percent). Furthermore, about one-half of the workers affected are covered by cost-of-living escalator clauses, the largest proportion recorded since such statistics were first compiled in 1957. 
It is not a simple matter to price out the impact of these escalator clauses, since they vary greatly in their terms. Many have guaranteed minimums, which were included in the 6.1 percent figure, or ceilings set at the top. In addition, the adjustment usually is less than 1 percent of wages for a 1 percent rise in prices. However, a rough judgment can be made by noting that, if the CPI rises by 3 percent, the average deferred increase will be 7 percent, rather than 6.1 percent.

Aggregate wage indexes. The behavior of the major wage series during the control period is shown in Table 2. A bulge in the magnitude of wage increases after November 14 reflects the concentration in late 1971 and early 1972 of increases that normally would have gone into effect during the freeze period. While the earnings series excludes any retroactive lump-sum payments resulting from the freeze, the compensation data were revised on an ex post basis to include these payments as having accrued during the freeze period. The earnings series declines more in the fourth quarter, which includes 1.5 months of the freeze, and shows a greater acceleration in the first quarter of 1972. Although the monthly data are more erratic, some of the bulge effects would be removed if the earnings data were reported on a December-to-March basis. The annual rate of increase would be 6.2 percent for all industries, as against the 8.6 percent shown in the table, and 5.7 percent versus 9.3 percent for manufacturing.

The second quarter of 1972 is the first period that reflects the full impact of the controls. The deceleration during that quarter was quite substantial in all sectors, and the wage increases came into line with the Pay Board standard of 5.5 to 6 percent. In contrast with the rate of increase before August 1971, the annual increments appear to have been reduced by about 1.5 to 2.0 percentage points. The decline is most notable in the contract construction industry, although the 4.8 figure may be somewhat transitory because the wage series for this industry is highly erratic in the short run. Since the difference from the earnings series cannot be explained by changes in fringe benefits or overtime, the low 4.4 percent figure for employee compensation appears to reflect some of the short-run problems of measurement that were discussed above.

Negotiated wage settlements run significantly above average earnings and are still above the Pay Board target. But they are heavily influenced by the catchup provisions, the importance of which should decline in the future. In terms of changes from the precontrol period, the results are quite impressive. The average decline in first-year adjustments was from 10.1 
percent in the first half of 1971 , to 8.4 percent in the first quarter of 1972, and to 6.6 percent in the second quarter.

The available data indicate that wage increases have slowed sharply in the contract construction industry, which is under the control of the Construction Industry Stabilization Committee. The first-year adjustment of contracts approved in the second quarter of 1972 averaged 6.4 percent, compared with 13.4 percent in the first half of 1971 and 17.6 percent in 1970. The low 4.8 percent figure for the increase in average hourly earnings in the second quarter may be somewhat erratic because of problems of seasonal adjustment. However, the BLS index of building trade union wage rates increased by 6.5 percent in the year ending in June 1972, as against 11.4 percent in 1971. Because of greater problems with a distorted relative wage structure, the CISC has relied less than the Pay Board has on a general standard. A larger proportion of the contracts have been altered by the committee, and individual settlements have shown wide variation. The committee has also modified a larger number of the deferred increases.

It is difficult to measure the precise impact of the controls in the construction industry. In some areas the union rates have not been paid because of increased competition from lower-wage nonunion workers. The construction trades do not constitute a completely closed shop, and market pressures undoubtedly had some influence in slowing the rate of wage increase.

Pay Board data. The Pay Board issues its own statistics on its approvals for categories I and II wage adjustments, in which increases averaged 4.9 percent through June 1972. Normally the aggregate figures include new and deferred adjustments but do not distinguish between union and nonunion workers. This has resulted in some confusion in relating Pay Board data to those of other agencies, such as the Bureau of Labor Statistics. The differences are due primarily to differences in coverage rather than in underlying data.

A reconciliation of the Pay Board figures for the first six months of 1972 with those for negotiated wage settlements as reported by the BLS is shown in Table 3. Categories I and II together cover unions of the same size as the BLS does $-1,000$ or more workers. The Pay Board approved pay increases that averaged 4.8 percent for 8.9 million workers during the period. This average was dominated by deferred increases, nonunion approvals, and state and local government wage decisions. All of these wage approvals are excluded from the BLS data. For the cases that are reported by both the BLS and the Pay Board, there appears to be no significant difference. The 
Table 3. Reconciliation of Pay Board and Bureau of Labor Statistics Data on Wage Increases, by Category, through June 1972

\begin{tabular}{|c|c|c|}
\hline Agency and data item & $\begin{array}{l}\text { Weighted average } \\
\text { wage increase } \\
\text { (percent) }\end{array}$ & $\begin{array}{l}\text { Number of } \\
\text { employees } \\
\text { (thousands) }\end{array}$ \\
\hline \multicolumn{3}{|l|}{ Pay Board, categories I and II } \\
\hline \multicolumn{3}{|l|}{ New and deferred cases, excluding retroactive } \\
\hline November 14, 1971, through June 1972 & 4.9 & 9,274 \\
\hline First six months 1972 & 4.8 & 8,921 \\
\hline \multicolumn{3}{|c|}{$\begin{array}{l}\text { New cases, excluding nonunion and governmental, } \\
\text { adjusted for classification and timing used by } \\
\text { BLS }\end{array}$} \\
\hline First six months 1972 & 7.4 & 673 \\
\hline \multicolumn{3}{|l|}{ Bureau of Labor Statistic's } \\
\hline \multicolumn{3}{|c|}{$\begin{array}{l}\text { Major private collective bargaining settlements, } \\
\text { excluding construction }\end{array}$} \\
\hline First six months 1972 & 7.4 & 703 \\
\hline
\end{tabular}

Source: Pay Board release PB-114, July 28, 1972.

a. Firms with 1,000 or more employees.

small difference in the number of cases involved can be traced to differences of classification of some bargaining situations that appear to have applied to the Pay Board as category III cases. In effect, the BLS data can be used as a fully appropriate measure of Pay Board actions for new contract settlements for large unions in categories I and II.

A more detailed view of the Pay Board's actions can be seen in Table 4, where a distinction is made between new and deferred adjustments and between union and nonunion settlements. The data differ from those in Table 3 since they include all approvals since November 1971 and wage approvals for government workers. First, it is clear that most of the deceleration is concentrated in new agreements, which averaged 4.8 percent. Normally, new increases substantially exceed deferred ones, but the very low rate of increase for new nonunion adjustments held down the average of total new adjustments to the rate of deferred increases. The union cases follow the traditional pattern, in which first-year adjustments ( 6.9 percent) exceed deferred increases (4.8 percent).

The deferred union adjustments can be changed only by specific Pay Board action since they are not subject to the general standard. Also they are sometimes divided into two or more adjustments within one year. Since the Pay Board measures the increase over the November 1971 level, the 
Table 4. Average Percentage Increases in Pay Packages Approved by the Pay Board through July 1, 1972, and Number of Workers Involved, by Union Status and Type of Agreement ${ }^{\mathrm{a}}$

\begin{tabular}{|c|c|c|c|c|}
\hline Union status & $\begin{array}{c}\text { New } \\
\text { agreement }\end{array}$ & $\begin{array}{c}\text { Deferred } \\
\text { agreement }\end{array}$ & $\begin{array}{l}\text { Type of } \\
\text { agreement } \\
\text { unknown }\end{array}$ & Total \\
\hline \multicolumn{5}{|l|}{ Union } \\
\hline Pay increase (percent) & 6.9 & 4.8 & 5.5 & 5.1 \\
\hline Number of workers (thousands) & 718 & 4,776 & 24 & 5,519 \\
\hline \multicolumn{5}{|l|}{ Nonunion } \\
\hline Pay increase (percent) & 4.2 & 4.8 & 4.3 & 4.4 \\
\hline Number of workers (thousands) & 2,518 & 759 & 32 & 3,309 \\
\hline \multicolumn{5}{|l|}{ Unknown } \\
\hline Pay increase (percent) & 4.8 & 5.9 & 1.3 & 4.6 \\
\hline Number of workers (thousands) & 58 & 31 & 17 & 107 \\
\hline \multicolumn{5}{|l|}{ All workers } \\
\hline Pay increase (percent) & 4.8 & 4.8 & 3.9 & 4.8 \\
\hline Number of workers (thousands) & 3,295 & 5,567 & 72 & 8,934 \\
\hline
\end{tabular}

Source: Pay Board, unpublished tabulation. The data exclude all retroactive pay increases arising out of the freeze period of Phase $I$.

a. Situations involving 1,000 or more workers.

first of any two-part increase would go into effect without challenge. Thus the greatest opportunity for the Pay Board to reduce these increases would come relatively late in the year. Through August 1972 the board acted to reduce deferred increases affecting only 100,000 workers, putting its major focus on new contracts.

The data clearly indicate that the 5.5 (or 6.2) percent guideline has not become a "floor" for nonunion settlements, as was feared by some. ${ }^{10}$ The distribution of increases in large union settlements in 1971 and 1972, shown in Table 5, also suggests that the general standard does not serve as a minimum target since the proportion of settlements below 5 percent has increased substantially, even though it is still not large. The major impact of the program has been to reduce the very large increases; settlements above 9 percent are much rarer in 1972 than in 1971. A minor but predictable repercussion of the program is the shortening of the average length of the contracts from thirty-four to twenty-five months. But with the exception of

10. The present data for nonunion employees may be biased downward by the fact that some may receive two increases during the year and the second would not yet be reflected in the data. 
Table 5. Distribution of Workers Affected by Initial Year Changes in Union Wage Rates, First Half 1971 and First Half 1972 Decisions $^{a}$

\begin{tabular}{|c|c|c|}
\hline \multirow[b]{2}{*}{$\begin{array}{c}\text { Amount of wage rate } \\
\text { increase }\end{array}$} & \multicolumn{2}{|c|}{ Percentage of workers affected } \\
\hline & $\begin{array}{c}\text { First half } \\
1971\end{array}$ & $\begin{array}{l}\text { First half } \\
\quad 1972\end{array}$ \\
\hline Under 5 percent & 2 & 10 \\
\hline 5 and under 7 percent & 27 & 32 \\
\hline 7 and under 9 percent & 13 & 30 \\
\hline 9 and under 11 percent & 29 & 18 \\
\hline 11 percent and over & 27 & 9 \\
\hline Not specified & 2 & $\cdots$ \\
\hline Total & 100 & 100 \\
\hline
\end{tabular}

Sources: U.S. Bureau of Labor Statistics, "Major Collective Bargaining Settlements, First 6 Months 1971," News Release USDL-71-416 (July 29, 1971), Table 3, and “. . First 6 Months 1972," USDL-72-512 (July 28, 1972), Table 3 . Percentages are rounded and may not add to 100 .

a. Bargaining agreements covering 1,000 or more workers.

contract construction, this reduction is less pronounced than might have been anticipated. Contracts have some tendency to be more back-loaded than they were before the controls, but this is primarily the result of Pay Board reductions in the first-year adjustments rather than a conscious prior restructuring by the parties at interest. There is also an increase in the frequency with which provisions are included for a wage reopening after one year or at the termination of the controls. There is little evidence of any efforts to alter normal contract provisions in order to avoid the regulations. A final gain associated with the program has been a general decline in the frequency and length of work stoppages during the control period.

It is difficult to determine whether, under the controls, the small unions and the nonunion sector are receiving treatment equal to that of the larger, more powerful unions. Adequate data are not available on nonunion wages for the precontrol period. However, their average increase could not have been far below the economy-wide average since 75 percent of the work force is nonunion. Nonunion wages have increased by a smaller percentage, but this is the result also of several other factors. Multiyear contracts are more common among the larger unions and are typically front-loaded so that the first-year increases exceed the later ones. Second, the problem of a catchup to restore normal wage differentials is greatest where there are multiyear contracts. Frequently the increases received under the prior contract were not as great as those received by other workers in the 1969-71 period. 
Problems in this area, if they exist, will become more obvious as the economy approaches full employment in future years, and we can more adequately judge differences in the availability of labor in different markets. Requests for exceptions from the general standard are less likely to come before the board in the case of nonunion workers, since the employer must first agree to a settlement above the board's general standard. However, most nonunion settlements are in category III, or they are exempt. Thus, unless the board gives the major unions larger increases than they would receive in the absence of controls, it is hard to see how the nonunion sector is worse off.

\section{IMPACT ON PRICES}

A significant slowing of inflation is evident in the behavior of most major price indexes. As was shown in the last column of Table 1, consumer prices have increased at an annual rate of 2.9 percent in the first eleven months of price controls, compared with a 3.8 percent rate prior to the freeze. The improvement is even more evident in the adjusted index for nonfood items, which excludes used car prices and mortgage interest rates, and which has advanced at an annual rate of 2.7 percent, compared with 5.0 percent before the controls. The deceleration of inflation is particularly dramatic in the area of medical care services, where the Price Commission has resorted to the use of an upper limit on individual price increases.

Aggregate price indexes. The measurement of price changes over the entire control period averages several subperiods with quite different performances. The freeze period of low inflation was followed by several months of substantial price rises. The commission allowed a catchup of prices similar to the wage catchup allowed by the Pay Board, and its attitude toward price increases was considerably easier early in the period than it was later on. In addition, food prices increased rapidly in the first few months of Phase II. These bulges are partially offset by a sharp drop in used car prices in the immediate postfreeze period. Thus the period since March 1972 offers a more realistic picture of progress made in slowing the inflation.

After rising at a rate of nearly 4 percent between November and March, the adjusted index for nonfood items has been increasing at an annual rate of 2.6 percent. Nonfood commodity prices rose in the recent period by 2.1 percent, in contrast with a 3.1 percent rate prior to controls. The rate of in- 
crease in service prices between March and July (3.9 percent) was about half of that in early 1971.

Food prices have been a continuing problem throughout the control period. Prices at the grocery store rose sharply in the immediate postfreeze period in response to increases in the wholesale prices of farm products. Food prices remained stable between March and June 1972 but have been rising rapidly in recent months. The increases reflect primarily supply problems and the fact that the economy is in the midst of a temporary cyclical upswing in farm prices. In general, manufacturers and retailers are free to pass these cost increases on to the consumer.

In view of the short-run rigidity of supply and the basic competitive nature of the food industry, this is not normally a sector where controls would be emphasized. But such reasoning is of slight consolation to wage earners who are asked to adhere to a pay standard based on a target rate for overall inflation of 2.5 percent. A similar round of food price increases stimulated concern about inflation on the part of the public in late 1965 and early 1966. Thus the coincidental timing of Phase II controls with a major rise in food prices has reduced public confidence in the program.

The wholesale price index does not present as favorable a picture of the trend of the inflation. Even if farm prices are ignored, the rate of price advance for industrials was 4.4 percent between March and July-only marginally below the rate of early 1971. The increases were concentrated in the intermediate and crude materials components, with the former having by far the greatest relative weight in the overall index. Most of the intermediate-goods-producing industries showed significant price increases following the freeze, the largest being in leather products, lumber, and textiles, where the basic influences appear to be changes in demand or supply rather than any institutional cost-push factors.

The higher prices of intermediate goods are not fully reflected in the prices of finished goods. While they show few signs of deceleration relative to the precontrol period, prices of consumer and producer goods have risen more slowly than the prices of intermediate goods. It is somewhat unusual to find such a long lag between changes in the prices of intermediate goods and of finished products, but this may be the result of delays faced by producers of finished goods in obtaining approval of price increases from the commission. Or it may be that they hesitate to request price increases. Also the strong upsurge in output during the first half of 1972, with the consequent spreading of overhead costs and large gains in productivity, may 
make it easier for these producers to absorb the increases in the prices of materials.

A comparison of the CPI and the WPI for finished consumer goods shows the same pattern-a greater reduction in the rate of increase for final products than for intermediate goods. In earlier periods this component of the CPI increased more rapidly than the corresponding component of the WPI as a result of rising trade margins. But this has not been the case in the Phase II period. Despite some differences in the product composition of these indexes, the more pronounced deceleration of the CPI may reflect a slowing in the rate of increase in retail margins. This would be consistent with the Price Commission regulation by which trade sector firms must maintain a gross profit margin no higher than that of the freeze period.

On the other hand, another factor may explain the observed differences between the rates of increase in prices of intermediate and of finished goods, and the lower rate of increase in the CPI components. The consumer price index is a measure of prices paid for actual purchases. In contrast, the WPI is a mixture of realized and list prices. In the current atmosphere of uncertainty about future Price Commission policy, some firms are reported to be raising their list prices in order to establish a high base-period price as a protection against future changes in the regulations. The term limit pricing agreements seem particularly vulnerable to these list-price changes when there is no change in realized prices. The practice of discounting below list price is more common in intermediate goods than in finished goods and may imply that some of the increase in these components of the WPI does not represent a real price change. ${ }^{11}$

The behavior of the fixed-weight private nonfarm deflator in the first two quarters of 1972 supports the view that there has been a significant decline in the rate of inflation. The second quarter rate of 2.3 percent is less than half the rate for the first six months of $1971 .{ }^{12}$ The slowing of price inflation on the whole matches the 1.5-2 percentage point slowdown in wages but does not fully match the decline in unit labor costs, which reflected a large gain in output per manhour. Past statistical studies have clearly shown that

11. A detailed explanation of the problem of interpreting the price indexes with respect to discounting below list is given in George J. Stigler and James K. Kindahl, The Behavior of Industrial Prices (National Bureau of Economic Research, 1970).

12. The decline in the actual deflator to an annual rate of 1.5 percent was even more pronounced, but it was heavily influenced by a shift in the mix of output toward goods with a lower rate of price increase since the hase period of 1958. 
prices are more sensitive to short-run changes in wage rates than in productivity. Since much of the shortfall in productivity growth during the 196970 recession was reflected in lower profit margins, it is to be expected that the cyclical upswing in productivity will not generate a commensurate price slowdown.

Price Commission data. It is difficult to draw many conclusions from the program data of the Price Commission, partly because very little information of even the most general sort about these data is made public. It is also difficult to know how to interpret the data that can be pieced together.

The Price Commission's activities are of primary importance in its dealings with the 1,500 Tier I firms, which account for over 30 percent of all industry sales. These firms must either receive prior approval for any price increases or enter into term limit pricing agreements. The proportion of the sales of various industry sectors that is accounted for by these firms is shown in column 1 of Table 6.

As of mid-August 1972 the commission had made decisions on 4,741 requests for price increases. Increases were granted in 93 percent of these cases and averaged 3.2 percent on applicable sales of $\$ 300$ billion and 1.7 percent on the total sales of the firms requesting increases. The size of the average price increase has been relatively constant during the course of Phase II.

The figures do include about 190 term limit pricing agreements covering $\$ 150$ billion to $\$ 175$ billion in sales. The agreements allow for an average price increase of about 2.2 percent on total sales. While the number of TLP agreements that have been ratified in recent months has continued to rise, the rate of increase has slowed, and most of the increases currently being granted come under the cost pass-through regulation.

Some industry breakdown of the approved price increases is available from the Cost of Living Council quarterly report of June 1972. The published data shown in column 3 of Table 6 include TLPs, which I have attempted to remove in column 5. The TLP agreements all provide for increases of close to 2 percent. Thus total approvals averaged 3.1 percent, of which TLPs accounted for 2.2 percent on total sales, and the non-TLPs 4.2 percent on applicable sales. Over 95 percent of the TLPs and 88 percent of the cost pass-through approvals were in the manufacturing sector. Tier I firms account for 67 percent of manufacturing sales, and half of the firms in this category have received approvals for price increases. Two-thirds of these increases were TLPs averaging 2.4 percent, and the cost pass-through 


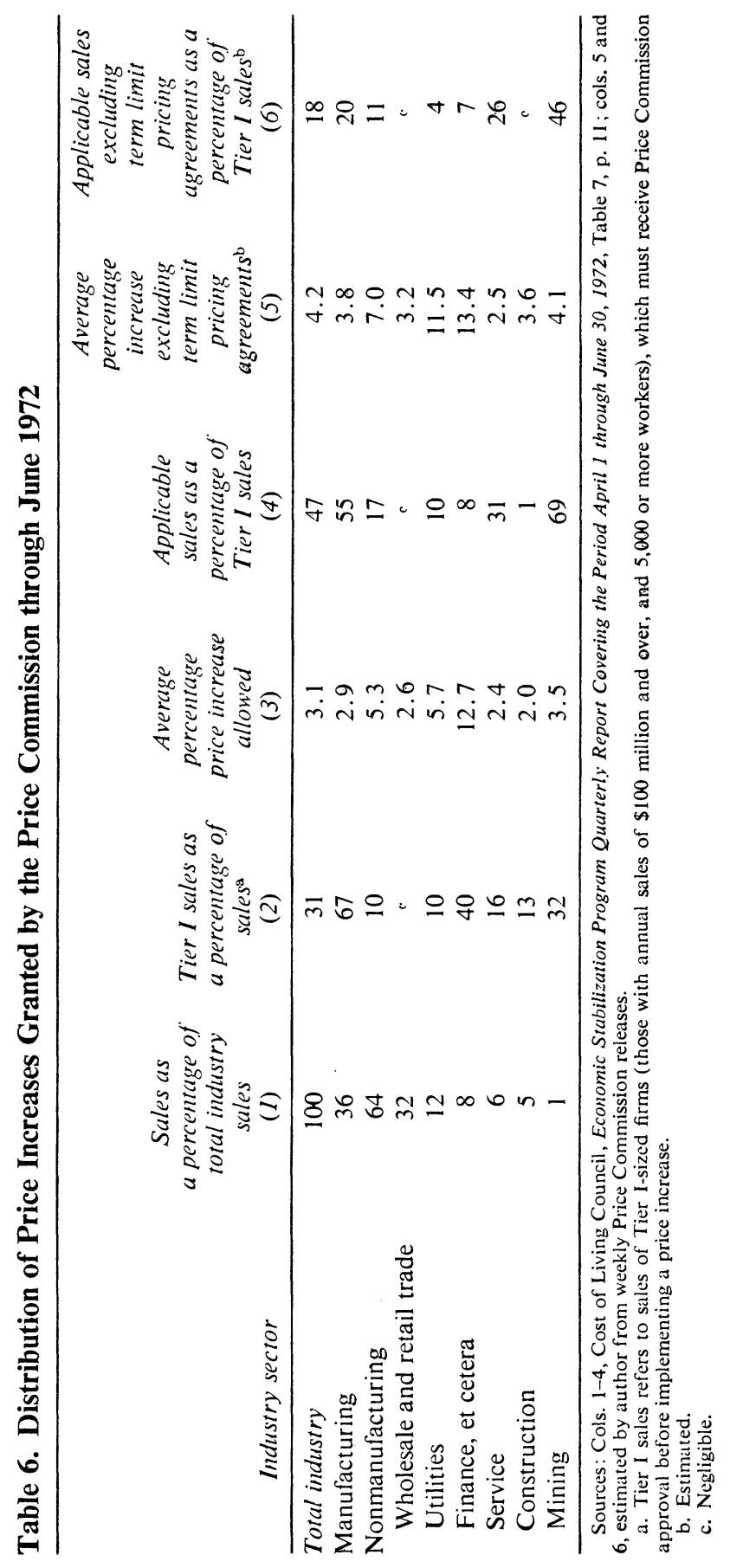


approvals averaged 3.8 percent. Increases in utilities and finance have been larger, but they are based on a small number of decisions. TLPs represent about 60 percent of all price increases approved through June 1972.

One difficulty with these increases is that the extent to which they have been implemented is not known-nor is the response of non-Tier-I firms in the markets where price increases were allowed. If these increases were put into effect and other firms matched them, the average increase of 3.8 percent for non-TLPs, representing about 20 percent of Tier I sales, would translate into an 0.8 percent rise in the manufacturing component of the WPI. But far more disaggregated data would be needed to make reliable calculations. It appears that not all of the TLP agreements have been fully implemented, but no information is available to the public on the amount of price change or on the specific product lines in which they have occurred.

The increases seem large relative to the target overall rate of 2.5 percentparticularly for the goods-producing industries, given their high productivity growth. But of course the figures do not include firms that received no increase. The margin between the 47 percent of Tier I firms at a 3.1 percent increase and the 53 percent at zero increase does seem rather wide.

One final problem exists in comparing Price Commission approvals with observed changes in the WPI and CPI. Through the end of August 1972 the Price Commission had approved price increases for Tier I firms amounting to $\$ 9.7$ billion in annual revenue. Yet if the increase in the industrial component of the WPI is applied to the sales of Tier I firms, the implied increase in revenue is 1.5 to 2 times as large. This conclusion holds even if the computations are done on a disaggregated basis. But in the explanation above of the rapid rate of increase in the WPI relative to the CPI, it was conjectured that these increases might be in list prices and might not reflect changes in prices actually paid. Yet the list price is what firms usually report to the Price Commission. Thus, if the WPI increases reflect only increases in list prices, it would appear that either Tier I firms are not receiving the same increases as other firms in their industry, or a substantial number of violations are occur ring. On the other hand, the substantial increases in the WPI may reflect actual price changes.

Price increases for most public utilities are not included in the above data since their applications for rate adjustments have been handled by the regulatory agencies since March 1972. Initially the Price Commission tried to review each of these rate adjustments before they were put into effect. It soon became clear, however, that the agencies were going to allow a sub- 
stantial number of large increases. Furthermore, the criteria established in the Price Commission's regulations did not match those of the regulatory agencies, and thus some confusion resulted. To solve this, after a onemonth freeze, the regulatory agencies were given the authority to approve rate changes, after first obtaining the Price Commission's approval of their proposed rules for use in considering requests for price increases. Under the new procedures, firms in the regulated industries are not subject to profit margin control. Instead, the agencies are to be guided by a general criterion under which a rate increase may be approved if it is justified by costs, or if it is needed in order to cover the costs of future expansion or to attract capital. In addition, rate changes are not allowed for the purpose of covering wage increases above the 5.5 percent standard; and unit labor costs must be adjusted to allow for anticipated growth in productivity. The general nature of these criteria implies that controls will probably have little impact on utility rates.

Data that are available from one quarterly review of utility rate increases during the control period show that in the second quarter of 1972, increases averaging 7 percent were approved on about one-fourth of total telephone company sales. ${ }^{13}$ Rate adjustments for gas and electricity averaged 6.4 percent on about one-third of industry sales. Increases in transportation averaged a much lower 1.6 percent on 10 percent of industry revenue.

These increases appear to be reflected in both the CPI and the WPI. Telephone rates in the CPI rose at an annual rate of 4.7 percent between August 1971 and July 1972. The rate of increase has been 4 percent since March 1972. Electrical energy rates have increased at a rate of 4.6 percent for the full control period and 5.7 percent since March. Electric power prices in the WPI have increased at a rate of 6.5 percent since August 1971.

The profit margin restriction became an increasingly important, although not necessarily effective, element of restraint as the program developed. Although it was originally viewed as a secondary line of defense, it has begun to exceed in importance the cost pass-through regulation. The latter control has proved to be very complicated to administer, and in practice it is flexible enough that most requests for price increases are found to meet its requirements.

On the basis of first quarter reports, 16 percent of 700 firms reporting in Tier I were above the profit ceiling. This does not include all of the Tier I firms since only those that raise their prices during Phase II are required to

13. Congressional Record, daily ed., August 17, 1972, pp. S13843-45. 
report. An additional 5 percent of the companies were estimated to be within 5 percent of the base period margin. Overall about one-third of the firms were within 15 percent; and about one-half were within 25 percent of the base period margin. Approximately the same percentage distribution appears to hold for Tier II firms.

Not all of the firms with profit margins above the base period level in the first quarter are in violation of the regulation. The restriction applies to the annual profit margins, and allowances are made for transitory influences on the quarterly reports. Through the middle of August 1972, forty violation orders had been issued for Tier I and Tier II firms.

The major industries that are close to the ceiling are food, tobacco, textiles, furniture, chemicals, and transportation. In the case of food and tobacco, this results not from a major cyclical increase in profit margins but from the fact that their profit margins are not cyclically sensitive and did not decline significantly during the recent recession.

The Price Commission has revised and tightened some of its rules as experience has revealed the need to do so. It required firms to use the commission's estimates of the trend of productivity growth in their industries when it became obvious that the firms' own low estimates were leading to consistently large estimated increases in unit labor costs. Second, it has refused to allow firms to use wage and benefit increases of more than 5.5 percent as a justification for a price increase, even when the Pay Board has approved the increase. Deferred increases of more than 5.5 percent must be passed through on a dollar-for-dollar rather than a percentage basis. This should encourage firms to participate actively in wage negotiations rather than relying on the Pay Board. Third, it has focused increasingly on the industry rather than on the individual firm, and considers many price increase requests as a package.

The commission has also expanded its use of such measures as ceilings on price increases permitted in certain areas-personal services, for example. This is similar to the procedure in the case of health care services, which has proven quite effective. Although there have not at present been large price increases for personal services, the commission has been concerned that there might be. Markup and margin controls were extended to the food processing industry. A dollar-for-dollar cost pass-through, rather than a percentage pass-through, was ordered for the leather industry. The smallfirm exemption was rescinded in the case of lumber, and the government arranged to release more timber acreage from its holdings. 


\section{SUMMARY}

Unmistakable signs of deceleration of inflation have appeared during Phase II. While the period of analysis is still very short and any firm conclusions must await the passage of time, the lower rate of wage increase is evident in a broad range of measures of wage rates. The same trend toward lower rates of inflation is found also on the price side, although the patterns are somewhat more divergent. The major improvements are in finished goods and medical care services. However, intermediate goods, public utilities, and some food prices have been problem areas. Certain individual sectors, such as construction materials, textiles, and leather products, have experienced demand pressures despite a general low level of resource utilization.

On the basis of these results it seems quite probable that the program will achieve a rate of wage increase near the end of the year of 5.5 to 6.0 percent. Price increases are not likely to get down to the target level of 2.5 percent. Nonfood commodities, however, appear to be within reach of a 3.0 percent rate of increase, though the rate for food prices is highly uncertain. Phase II has not brought an end to inflation, but the results thus far should set the stage for a tightening of the regulations on both prices and wages in future months.

What these statistics do not prove, however, is that the controls are responsible for the improvement. Some may argue that the inflation would in any case have slowed down by about the amount it has. However, the coincidence of timing seems unusual, to say the least. Two and a half years of rising unemployment brought very little slowing of the price and wage increases; and the kind of general slowing of wage and price increases that has taken place in recent months certainly did not occur in the immediate precontrol period.

The major impact on prices and wages does not appear to come from specific decisions of the Pay Board or the Price Commission. The actions of the Pay Board in reducing individual contracts account for, at most, a reduction of a couple of tenths of a percentage point in the average of wage increases during Phase II. The Price Commission similarly has approved an overwhelming proportion of requests for price changes. The restraint appears to come instead from the changed environment in which price and wage decisions are made-particularly the published 5.5 percent (or 6.2 percent) general wage standard. Wage control is effective primarily because 
it is in the self-interest of employers to comply. The lower rate of price inflation appears to be partly a reflection of a slower increase in wage costs. But additional areas of restraint are evident in medical care costs and perhaps trade margins.

\section{Some Operational Problems}

The Phase II controls program has changed considerably since its inception. Much of the original rhetoric seemed to indicate that it would be a "crunch" program, of relatively short duration, that would quickly restore price stability. However, the program as it actually is operating reflects a more gradual approach to dampening inflation. After some experience with controls, it became clear that a simple freezing of the relative wage and price structure as it was in November 1971 would have been inequitable and inefficient. The problems in this area were complicated by long contract periods and lags in decision making in both the labor and the product markets. A preference for gradualism is apparent in the tandem and catchup provisions of the Pay Board and in the cost pass-through and profit margin regulations of the Price Commission. Because of the actions of Congress, which exempted fringe benefits and raised the wage increase standard from 5.5 to 6.2 percent, there may be even more gradualism than was intended.

The present program emphasizes restraint primarily in the wage area; firms may pass on increases in costs through price increases on a percentage basis. Overall this approach may be appealing. Labor costs are by far the largest element in the cost of total output, and a permanent slowing of inflation cannot be accomplished without a matching deceleration of wage increases. Since profits represent a relatively small percentage of total income, even a large proportionate reduction in margins would have only a relatively small, one-time impact on the rate of inflation. Also it is argued that most empirical studies indicate that prices do little more than respond to cost increases; aberrations are observed primarily in competitive industries that experience large variations in demand and supply. Although the situation might be different in a few concentrated industries, these arguments challenge the need for price controls, except in a few concentrated industries, and suggest reliance on the Pay Board for a solution to the inflation problem. 
But this singular focus on wages I believe to be the most serious difficulty of the current program: Controls can operate in a democratic society only in an atmosphere of widespread public confidence. Above all the program must maintain at least the appearance of equity in its treatment of all groups. It would be hard to imagine calling out the National Guard to force workers back to work. A system where the government, rather than the employer, is the principal negotiator with employees is not likely to be viable. Unions are asked to adhere strictly to the terms of contracts in order to prevent wildcat strikes and other disruptive practices. But this will be difficult to do if the government is constantly in the position of invalidating contracts that have been signed voluntarily by both parties.

Furthermore, attention has been directed to the large wage increases that were obtained by workers in some sectors prior to controls; but equally impressive is the willingness of firms to pay them. This is to some extent the result of a growing awareness on the part of firms that it is not the absolute size of the wage increase that matters, but rather its size relative to what the firms' competitors will pay. Assurances that these wage rates will be the pattern for the rest of the industry allow the firm to pass on the costs through a price increase and leave it in the same competitive position as before. If imports become a problem, the industry will look to Congress for more protectionist measures.

There is some evidence at present that the size of wage increases requested of the Pay Board is rising rather than falling. Individual firms have great incentives to surrender their bargaining function to the Pay Board and seek relief from the resulting cost increases by appealing to the Price Commission. Wage restraint is an important part of a controls program; but it must be balanced by an equally restrictive policy on price increases in order to insure that the government does not simply replace the employer as the bargaining agent.

Finally, the poor performance of productivity in recent years has contributed to inflation. Though the economist may stress the role of capital and technological change in this area, the role of the entrepreneur is frequently overlooked. Costs are not an exogenous variable to the firm. The businessman receives a profit in return for achieving more efficient methods of production. But, for firms with a strong market position, raising prices is an easier way than cutting costs to achieve satisfactory profits. Thus excessive market power may reveal itself more in a careless approach to controlling costs than in high profits. 
It would appear that a viable program must place a heavy emphasis on reinforcing market pressures against price increases. This is necessary to induce firms to direct more effort toward reducing their costs as a means of increasing profits. The government's role in labor negotiations must be largely the indirect one of stiffening business resistance to excessive wage increases. In individual cases direct action may be needed to prevent the kind of large wage increase in a specific sector that can stimulate another round of wage inflation.

The regulation adopted by the Price Commission after the coal settlement, which does not allow a price adjustment to cover a wage increase in excess of 5.5 percent, is in concept a step in this direction. It strengthens the employer's concern with the original wage settlement, since an agreement on a wage increase may not be cut back by the Pay Board and the firm may be forced to cover the cost increase out of profits. But in practice most of this restraint is lost because of the looseness of the cost pass-through regulation. Firms can cover the excess wage increase by raising the estimate of other components of total costs.

\section{PRICE CONTROLS}

In adopting a program of price controls, as in wage controls, government decision making need not supplant that of the market participants. The controls should reinforce the basic pressures of the market. Yet current price controls appear to be inconsistent with this objective.

I take as a general model of the pricing behavior of a competitive firm one in which it charges a price that represents a markup over its marginal costs. This markup should be a function of the price sensitivity, or elasticity of demand, the individual firm faces. The formal economic statement of the price that maximizes profits is given by

$$
P=\frac{e}{e-1} \cdot M C,
$$

where $P$ equals price, $e$ equals the elasticity of demand, and $M C$ equals marginal costs. Thus a firm in a perfectly competitive market with a demand elasticity of infinity will have its price equal to marginal costs, and no rational firm will purposely sell in the inelastic portion of its demand curve. In practice, the demand elasticity of differentiated products will lie between these extremes; and empirical studies have indicated that the mar- 
ginal costs of most industries are constant over a fairly wide range of output. Thus the businessman's concept of direct unit costs is a close approximation of marginal costs. The firm may set its markups more by trial and error or on the basis of historical experience, but market pressures will lead the successful firms toward the profit-maximizing price defined above. Markups will not change greatly unless there are substantial changes in competitive structures over time.

The important issue for price controls is the emphasis, in normal pricing decisions, placed on marginal or direct unit costs rather than on average total costs. But the current cost pass-through regulations for manufacturers stress the latter rather than the former concept. The regulation does not have a valid economic rationale, nor does it reflect the pricing practice of most firms. The procedure is in contrast to the regulations for the trade sector, which stress marginal or invoice costs, rather than total costs.

In practice, the regulation is so difficult to administer as to be unworkable for manufacturers. Any decision on allocating the joint operating costs and overhead costs of multiproduct firms is so arbitrary as to give individual firms wide discretion in their justification of price increases. Once the Price Commission becomes entangled in the web of accounting problems involved in dealing with an individual firm, it is at a severe disadvantage, for it will never understand the firm's operations as well as the firm's own managers do. Since the regulation is oriented toward the individual firm rather than the market, the commission has difficulty in verifying cost increases using existing government data. In contrast, a firm's direct costs are mainly those of wages and materials, for which government data, wage agreements, and invoices provide a significant amount of information on an industry-wide basis.

The term limit pricing agreements were part of an attempt to reduce the administrative burden of the controls. Individual firms agreed to hold their average price increases to about 2 percent, with a maximum of 6 percent for an individual product line. These firms also remain subject to the profit margin restriction.

The result of the regulation, however, has been to release firms with high productivity growth (which might have been pressed for price reductions) from the controls. It has also given these firms a high degree of price flexibility. They can raise prices on products in which they have significant market power and leave prices unchanged in the competitive areas. The TLPs were attractive to firms as well as to the Price Commission, but little attempt 
was made to negotiate the average size of the increases. They averaged 2 percent. But average price increases in some industries should have been held close to zero. In other industries with large potential cost increases, even price increases far above 2 percent would represent substantial restraint.

Both the complexities of applying the cost pass-through regulations and the broad area covered by price controls create a heavy administrative burden that distorts the focus of the program. These problems have forced the commission to rely on the profit margin restriction as a primary means of control, rather than as a secondary line of defense, as was originally intended. In effect this is simply another way of looking at total costs. Both regulations are equivalent to an excess profits tax, with the difference that the excess profits are to be paid to the consumer rather than to the government. Thus they are subject to all the early criticisms of the use of this tax.

In addition, it is difficult to see how the change in an individual firm's profit margin since 1968-69 can be correlated closely with the need for price increases or reductions in the markets in which it operates. The fact that a firm's profits have been reduced by cost increases does not necessarily mean that its prices should be raised. The emphasis should be placed first on cost reductions. In addition, profit margins will be strongly affected by cyclical fluctuations in sales and in the mix of products sold.

The current regulations appear to encourage firms to let costs rise so that they may raise prices and receive an equivalent percentage increase in profits. Incentives toward price collusion are strengthened. The regulations lead to abnormalities; for example, firms do not fund short-term debt into long-term because the former is an allowable cost and the latter is not. On the profit side, interest on borrowed capital is not part of profits, but the return on a firm's own capital is. Maintenance and other activities of a semi-investment nature can be accelerated while the Price Commission is in existence, with the consequent shifting of profits into the future in anticipation of its demise.

Given the commitment to do so, what is the proper way to regulate pricing decisions? I would prefer the type of regulation that strengthens the basic market pressure on prices, rather than one that attempts to supplant the market mechanism. If the commission focused on direct labor costs (with estimates of productivity growth in the industry) and materials costs, and ignored overhead costs, it would have a more meaningful basis for evaluating requests for price increases. The controls could then be directed toward markets rather than toward individual firms as a means of strength- 
ening incentives for cost reductions. Measuring profits is useful primarily as an ex post means for determining areas of the economy in which the commission has been too rough or too easy.

Accounting complexities would remain even with these modifications. Without extensive administrative machinery, no system of comprehensive price controls can be managed effectively. The very complexity of the issues involved sharpens the need to focus the efforts of the Price Commission on the more significant industries where it will have an important impact.

Exempting firms with sixty or fewer employees did substantially reduce the coverage of the program since it affected about 5 million firms with 19 million employees and $\$ 500$ billion in sales. But most of the commission's administrative activities are associated with the 1,500 Tier I firms which account for 30 percent of total sales. The Internal Revenue Service also has a heavy burden in monitoring Tier II firms though this has little impact on the price level.

One of the difficulties with redefining the size of Tier I firms so as to exercise better control is that there is little connection between firm size and the likelihood that controls will be constructive. Firm size does not indicate accurately either market power or industries in which controls can be most effective. The fields of health services and construction are examples of this type of problem. A more adequate definition of problem industries than one based on firm size is needed if the dimensions of the category are to be reduced. One possibility is to make the definition a flexible one in which firms are moved in and out of Tier I as pricing problems develop in their industry.

\section{WAGE CONTROLS}

Wage controls appear to impose far fewer administrative problems than do price controls. The Pay Board regulations have not required the kind of large bureaucracy that developed in the Price Commission. Part of the reason is that one of the private parties involved in wage regulations-the employer-is normally interested in their enforcement. The Price Commission has no such advantage. Wage controls, however, do involve complex issues of relative wage differentials. In the absence of controls, wages are not determined purely by the interaction of demand and supply but are heavily influenced by the relative market power of the employer and employee. The Pay Board has been given no clear standards to guide it in de- 
termining the "correct" relative wages of different groups. It is thus frozen into maintaining the existing wage structure, which will not be accepted by all. Alternatively, the issue of what constitutes a "fair" wage also creates the risk that the Pay Board will become a tool for income redistribution; but while a redistribution of income might be a desirable objective, a pay board would probably not be the best means for accomplishing it.

The requirement of the stabilization act that the board take account of "productivity bargaining" in its decisions is fraught with similar dangers. If a few of the less responsible unions try to use old work rules as a means of achieving larger wage increases, others must in self-defense follow suit. Unions that previously displayed a flexible attitude in allowing management to vary work patterns will use such rules changes as a device for exceeding the general wage standard. Except in isolated instances the buying out of restrictive work rules is not a good practice.

Many of the problems associated with wage controls have not yet developed in the United States because of excessive slack in the labor market. But the problems will intensify as the expansion continues. In contrast to this year, 1973 will be a year of extensive collective bargaining activity. Many major union contracts will come before the Pay Board, and exceptions to the general standard will become less easy to justify because of the declining importance of the catchup and tandem provisions of the current regulations. The general standard was raised to an effective rate of 6.2 percent by the action of Congress in exempting many fringe benefits and will obviously have to be tightened. But such restriction will be difficult to achieve until a better performance of consumer prices can be achieved.

\section{Conclusion}

Price and wage controls have not as yet been the unmitigated disaster that some predicted they would be. Nor have they been a panacea for all our ills. As with most things in life, they have been a mixed bag. The evidence presented here as to their impact is highly tentative. Because there are problems now, and more will probably develop in the future, the program will need to be continuously revised to meet changing conditions. The inability to hold to an acceptable rate of inflation at an acceptable level of unemployment can be interpreted as a need to change the system. Wage and price controls are an extreme form of such change. Our own past ex- 
perience, and that of other countries, strongly implies that they are not a permanent solution, but they give us time to undertake more fundamental corrections.

It is discouraging to find so little evidence of serious planning for a Phase III period for restructuring problem industries. The government could play a significant role in cooperating with labor and business to moderate the pressures that develop in specific sectors of the economy and to improve their ability to adjust to these pressures without major price increases. This role may call for changes in import controls, the occasional use of government stockpiles, subsidies, and support prices as a means of stabilizing individual markets, and a change in laws that interfere with the smooth transfer of resources among sectors. A multitude of proposals have already been made for upgrading the quality and mobility of labor. Similar improvements could be made in the product markets to strengthen competitive pressures and to promote efficiency. I doubt that these measures are as direct as breaking up large firms and large unions, but the government need not limit itself to reviewing passively the price and wage increases submitted to it.

Price and wage controls are not generally popular among economists. Certainly they are anathema to the type of economy outlined in the textbooks. But the correspondence between the static world of the textbook and the real world we live in is sometimes itself difficult to discern. The realities dictate that there can be no sharp line of demarcation between the private and the public sectors. Private decisions must have some regard for their larger implications. It may be possible to alter the economic structure so that externalities are adequately reflected in private decisions, but this will take time. In the meantime, government participation in wage and price decisions need not mean the end of the free market economy. There is no need for a pervasive system of government control, but there is a need to recognize that different sectors of the economy have different characteristics and as such require different public policies. If some progress in reducing inflation was a political prerequisite for redirecting fiscal and monetary policy toward reducing unemployment, the controls have thus far been a cheap price to pay. 